ORIGINAL ARTICLE

\title{
Can close romantic relationships last? The commitment of partners in married and cohabitant couples
}

\author{
Iwona Lidia Janicka (D) A,B,D,E,F, Wiestaw Szymczak (DD B,C,D,F \\ Institute of Psychology, University of Lodz, Poland
}

BACKGROUND

Western studies indicate the significance of commitment in close emotional relationships. Interpersonal commitment is regarded as a process which is indispensable for building and strengthening close relationships, and is associated with the continuation of relationships between happy or unhappy partners. With this in mind, interpersonal commitment is an important topic for analysis. A theory by Stanley and Markman served as the inspiration for conducting studies on the commitment of partners in permanent relationships in Poland.

\section{PARTICIPANTS AND PROCEDURE}

The results for 260 couples (160 marriages and 100 cohabiting couples) were finally submitted for analysis. All the participants $(N=520)$ were aged from 19 to 68 $(M=33.01, S D=11.16)$. The mean ages of the participants were 31.98 years $(S D=10.95)$ for women and 34.03 years $(S D=11.30)$ for men. The Interpersonal Commitment Questionnaire (KZI) was used to analyse the perception of the relationships; this is the Polish version of the Commitment Inventory by Stanley and Markman.
RESULTS

The present findings indicate that marriages tend to portend better than cohabitations. The permanence of marriage is based on dedication, reflecting the significance of the relationship, and constraint commitment, which regards concern for the partner's well-being. The latter may hinder partners, especially men, from leaving the relationship.

\section{CONCLUSIONS}

Studies conducted in Poland tend to produce very similar results to those performed in the US concerning the level of commitment by partners in cohabiting relationships. It may be concluded that the type of commitment is specified more closely by the form of the relationship rather than the socio-cultural conditions in which the couples live.

\section{KEY WORDS}

questionnaire; marriage; cohabitation; interpersonal commitment

CORRESPONDING AUTHOR - Prof. Iwona Lidia Janicka, Institute of Psychology, University of Lodz, 10/12 Smugowa Str., 91-818 Łódź, Poland, e-mail: iwona.janicka@uni.lodz.pl

Authors' contribution - A: Study design · B: Data collection · C: Statistical analysis · D: Data interpretation ·

E: Manuscript preparation · F: Literature search · G: Funds collection

TO CITE THIS ARTICLE - Janicka, I. L. (2019). Can close romantic relationships last? The commitment of partners

in married and cohabitant couples. Current Issues in Personality Psychology, 7(3), 203-211.

RECEIVED 03.02.2019 · REVIEWED 14.05.2019 · ACCEPTED 16.05.2019 • PUBLISHED 18.06.2019 


\section{BACKGROUND}

Cohabitation is growing in popularity as a form of common life between partners. It is defined as "[...] the status characteristic of unmarried, sexual partners who share their household" (Popenoe \& Whitehead, 2004, p. 20), an intimate relationship of a sexual character between unmarried partners who live together for a longer time (Xu, Hudspeth, \& Bartkowski, 2006), or the shared accommodation of partners who are linked by an intimate, close bond (Gold, Sen, \& Hayward, 2010). Cohabitation may be treated as an alternative to marriage when partners do not intend to marry, or as a premarital trial intended to verify both partners' capabilities and readiness for common life. It may also serve as post-engagement cohabitation, i.e. a stage that directly precedes marriage. Among young adults, it is particularly common to see cohabitation used as a premarital trial, a form of relationship which became very popular in the United States in the 1920s, and in Poland in the 1990s. Keong-il (2008) defines premarital cohabitation as an agreement made for a definite period of time between partners who live together to determine whether they are fit for marriage.

The number of cohabitation relationships in the West has risen since the 1970s, and the same has been observed in Poland since the end of the 1990s. Cohabitation has been found to be the most popular in Norway, where around $90 \%$ of all couples cohabit (Mortensen, Torsheim, Melkevik, \& Thuen, 2012), while this number falls to around $60 \%$ in the United States (Hsueh, Morrison, \& Doss, 2009). In Poland in 1974, the number of such cohabiting partner relationships was estimated at 90 thousand, which constituted around 1\% of all relationships (Chechliński, 1981). Partner relationships were included in the General Register for the first time in 2002; since then, General Statistical Office data indicate that the number of cohabitations has risen from 198000 to 397000 in recent years (General Statistical Office, 2016). However, these figures may not accurately reflect the popularity of cohabitation in Poland: the number of cohabitating relationships may well appear less frequent than in other countries due to the reluctance of couples to admit to cohabitation. Poland remains a Catholic country, and one with Catholic traditions. There is generally a lack of acceptance of unmarried couples living together. There were times when getting married was not only expected, but even encouraged by legislation; for example, in the years 1956-1973, all unmarried men above the age of 25 were subjected to a raised income tax known as the 'bachelor tax'.

Even now, married persons still arguably maintain a higher social standing than cohabiting persons or singles, and this may be why Polish partners typically declare that their cohabitation is a stage which precedes marriage. Such couples may justify their status of not being lawfully married by their financial and housing situation, lack of job stability, the demands placed on them by their career, or by their young age (Janicka, 2006). Furthermore, unmarried couples in Poland do not have the same rights as married ones, with the pro-family policies of the Polish government favouring marriages with children and single parents.

Even so, families in Poland still face difficult conditions, with a lack of available childcare facilities such as nurseries and kindergartens, particularly in the larger cities, where parents work professionally and most cannot afford to hire a babysitter. It is not uncommon for women to register their unborn children on waiting lists for nursery as early as in the first month of pregnancy. Such activities do not apply to single parents, as their children can be enrolled in nursery, kindergarten or after-school clubs without having to wait, and a single parent may claim child benefit, in the case of low income, or reclaim child care costs in the case of unemployment. A single parent may also file a joint tax return with the child, resulting in a tax deduction being made, and in a tax-free sum being deducted twice. Paradoxically, in some regards, life can be easier for single parents in Poland than cohabiting parents.

Despite these inequalities between married or single parents and those who are cohabiting, society is becoming more open to alternatives to marriage, as illustrated by the growing trend to accept and practise cohabitation.

It is important to conduct studies examining the formation and maintenance of close relationships; such an analysis may indicate that the commitment is specified in a more distinct way by the form of the relationship rather than the socio-cultural conditions in which couples live. Studies indicate that cohabitation presents a risk for the quality and stability of both the informal relationship and any future marriage. In cohabiting relationships, negative interactions, problems with communication and quarrels between partners have been found to occur more frequently than in marriages (Binstock, 2003; Brown, 2003; Brown \& Booth, 1996; Janicka, 2008; Kline et al., 2004; Thomson \& Colella, 1992). It has also been found that lengthening the period of cohabitation increases the risk of failure for a relationship (Janicka, 2009; Stanley, Rhoades, \& Markman, 2006; Stanley, Whitton, \& Markman, 2004). Moreover, post-cohabitation marriages tend to disintegrate earlier (Janicka, 2010), and persons who remain in an informal relationship present less interest in marrying their partners than they did before starting cohabitation (Rhoades, Stanley, \& Markman, 2012a).

The increased risk of splitting up is explained by the effect of cohabitation. It strengthens the temporary nature of the relationship, which does not favour the stability of the cohabitation itself or of the 
post-cohabitation marriage (Brown \& Booth, 1996; Mortensen et al., 2012; Smock, 2000; Stanley et al., 2006; Xu et al., 2006). This elevated risk is related to certain specific characteristics of a non-legalised relationship; the partners may develop the conviction that they always can give it up and lack any structural difficulties with leaving it. It has been claimed that partners do not invest in a relationship which is not treated as stable (Owen, Rhoades, Stanley, \& Markman, 2011). Furthermore, individuals who hold decay theories of passion may be less likely to put effort into maintaining a passionate relationship, leading to lower commitment (Carswell \& Finkel, 2018).

With this in mind, interpersonal commitment is an important topic for analysis. It is regarded as a process which is indispensable for building and strengthening relationships between partners. Commitment is associated with the continuation of relationships between happy or unhappy partners (Pryor \& Roberts, 2005); it is expressed as either the will to stay in a relationship or a sense of duty (Rhoades, Stanley, Kelmer, \& Markman, 2010), and it plays an important role in the process of partner matching (Rhoades, Stanley, \& Markman, 2012b). Similarly, commitment is understood by cohabiting and married persons as loyalty, but also as responsibility and life based upon vows (Pryor \& Roberts, 2005; Schoebi, Karney, \& Bradbury, 2012).

Classification of commitment has been provided by four studies (Rhoades, Stanley, \& Markman, 2006, 2012a; Rhoades, Stanley, \& Markman, 2009; Rhoades et al., 2010) on the basis of earlier work by Stanley and Markman (1992). These works distinguish two constructs in the theory of commitment: interpersonal commitment, defined as dedication, and constraint commitment, which are equivalents of the psychological meanings of the phrases I want and I must. Dedication is related to the desire to maintain the relationship with a partner and concerns the sense of a bond: one's internal sense that a shared entirety is formed together with a partner. The needs of the partner and the relationship, and the readiness to devote oneself to the partner, are given priority. Dedication leads to thinking in terms of 'we' and to the desire for a common future.

In contrast, constraint commitment concerns the tendency to involve oneself in behaviours that are related to maintaining the relationship. It reflects all the links whose disintegration would incur higher costs than staying in the relationship. Constraints pertain to internal or external powers that encourage the partners to stay together. The internal constraints, defined as sacrifice, which are related to the sense of responsibility and duty to stay in one's relationship, may include inter alia some moral and religious rules regarding living together, or anxiety about the partner if he or she were to be left alone. These constraints are referred to by the authors as a feeling of pressure. External constraints, on the other hand, are defined as the compulsion to stay in the relationship, and can include the presence of children, pressure from family and friends, a financial investment in the relationship, common resources and difficulties in dividing them. The reasons enumerated here explain why relationships are maintained despite a lack of satisfaction in a partner. Feeling constraints may slow the process of disintegration, but does not necessarily protect against it (Rhoades et al., 2010).

This way of defining commitment, as sacrifice and compulsion, may seem negative, but it can also motivate partners to continue their relationship despite the difficulties and problems they experience. Sacrifice and compulsion are positively related to one another, yet they display a negative correlation with dedication (Kelmer, Rhoades, Stanley, \& Markman, 2013; Knopp, Rhoades, Stanley, \& Markman, 2015; Lemay, 2016; Rhoades et al., 2010), and a positive correlation with psychological insecurity and anxiety about resignation (Knopp et al., 2015). It has been demonstrated experimentally that the two commitment constructs, though different, are mutually dependent and related to one another, suggesting that they act together in order stabilise a relationship (Givertz, Burke, Segrin, \& Woszidlo, 2016; Stanley \& Markman, 1992). The ideal situation occurs when a person both wants and feels obliged to stay in a relationship. Some studies confirm a mutual dependence between satisfaction with a relationship and commitment to it, with a more satisfying relationship between partners being accompanied by an increase in commitment (Givertz, Segrin, \& Hanzal, 2009; Givertz, Segrin, \& Woszidlo, 2016a; Landis et al., 2014; Lemay, 2016).

A theory by Stanley and Markman (1992) served as the inspiration for conducting studies on the commitment of partners in permanent relationships in Poland.

\section{PARTICIPANTS AND PROCEDURE}

The study examined 300 heterosexual couples (600 participants). After rejecting incomplete questionnaires, the results for 260 couples (160 marriages and 100 cohabiting couples) were finally submitted for analysis. All the participants $(N=520)$ were aged from 19 to $68(M=33.01, S D=11.16)$. The mean ages of the participants were 31.98 years $(S D=10.95)$ for women and 34.03 years $(S D=11.30)$ for men.

To accurately compare the cohabiting and married relationships, it was necessary to ensure that the groups were similar with regard to certain conditions and some demographic variables. Therefore, the two groups were matched with regard to age and level of education. Education determines the social, occupational, and economic status of a relationship, and 
homogeneity of education between partners is especially favourable as it exerts a positive influence upon the stability of relationships, particularly non-marital ones (Nave-Herz, 2003). Hence, all couples had similar levels of education, i.e. higher or secondary, and were professionally active. It was not possible to preserve the similarity with regard to the seniority of the relationship between married and cohabitating partners. Cohabiting couples were characterized by a much shorter relationship length than that of married ones. This was also true for older partners, for whom it was not the first cohabitation or who (in the majority) were divorced. The participants were of heterosexual orientation, of Polish nationality.

The couples were recruited to the study in the years 2016 and 2018. Participant selection was performed according to the snowball procedure. The sample was chosen according to the following criteria: experience of at least one year of common life, no complaints of any chronic physical or mental diseases, and sharing a common household. All participants gave their consent to take part in the study. The partners filled in a demographic survey and the Polish version of the Commitment Inventory (KZI) independently, using the paper-pencil method.

\section{MEASURE}

The KZI was used to analyse the perception of the relationships; this is the Polish version of the Commitment Inventory by Stanley and Markman (1992) The adaptation of the Stanley and Markman Commitment Inventory was performed according to the following steps: translation of the method into Polish, examining equivalence of the English and the Polish versions, verifying factor structure, and determining the psychometric characteristics of the Polish version (Janicka \& Szymczak, 2017).

The Polish version has three factors that were distinguished: bond with the partner, significance of the relationship, and concern for the partner's well-being. The first factor, i.e. bond with the partner ("I want to be with my partner"), consists of 11 items pertaining to closeness, emotional bond with the partner, fulfilling undertaken obligations, sacrificing for the partner. The second factor, significance of the relationship ("I want to stay in the relationship"), made up of 5 items, is linked to taking the relationship seriously, not acknowledging its ending and acknowledging a mutual dependence between partners. The third factor, concern for the partner's well-being ("I must/should stay in the relationship"), comprises three items that indicate the feeling of being kept or trapped in the relationship. The Polish version of the Commitment Inventory (KZI) includes the same items that are contained in the Constraint Scale in the original version, i.e. the dimension of concern for the partner's well-being (Rhoades et al., 2010). They refer to feelings that would be related to leaving the relationship. A partner may feel obliged to stay in the relationship because parting would cause a sense of guilt, it would expose the partner to various types of difficulties that he/she could not cope with, it would be perceived by the abandoned partner as a painful experience, and it could even lead to 'ruining' his/her life. This dimension does not refer to specific constraints that force somebody to stay in the relationship (e.g. properties, children, pressure from family or friends), but it does not exclude them either. However, it primarily refers to the feelings and outcomes predicted by the leaving person, together with evaluations of the new life situation experienced by the abandoned person as a result of leaving. This factor may be considered as universal for all obligations associated with being in a relationship.

As with the original version, each given statement is assessed on a 7-point scale from 1 (strongly disagree) to 7 (strongly agree).

The reliability of the KZI was assessed using Cronbach's $\alpha$. The examined factors were characterised by satisfactory internal consistency ranging from .71 to 89 .

The obtained results were analysed using a twoway (marriage/cohabitation, gender) analysis of variance, with simple effect evaluations (Winer, Brown, $\&$ Michels, 1991). The significance level adopted for the applied tests was $\alpha=.05$.

\section{RESULTS}

The KZI, i.e. the Polish version of the Commitment Inventory, comprises the three commitment factors described earlier, namely bond with the partner, significance of the relationship, and concern for the partner's well-being. The two first factors pertain to commitment meant as dedication, and the third one regards constraint commitment, this being the obligation to stay in the relationship.

Based on these three factors, the subjects were compared in terms of their relationship type (marriage, cohabitation) and their gender. The results are presented in the tables below.

Gender did not appear to differentiate between partners from cohabiting relationships and those from married relationships (Table 1). However, cohabiting men and women were found to feel more emotionally attached and more satisfied with their common life than married women and men $(p<.0005)$ (Table 1$)$. A similar direction of differences was obtained when cohabitations were compared to marriages (Table 2), with the cohabitants displaying a stronger bond with their partner than the married persons $(p<.0005)$.

The married couples regarded their relationship as more important than the cohabitants $(p<.005)$ (Table 2); this was also observed when married men were compared with cohabiting men $(p<.05)$ and 
Table 1

Results for dependencies among gender, type of relationship, and bond with the partner, significance of the relationship, concern for the partner's well-being

\begin{tabular}{|c|c|c|c|c|c|}
\hline \multirow[t]{3}{*}{ Gender } & \multicolumn{4}{|c|}{ Type of relationship } & \multirow{3}{*}{$\begin{array}{c}\begin{array}{c}p \text { in interaction effect test } \\
\text { (comparisons within a gender) }\end{array} \\
\text { Bond with the partner }\end{array}$} \\
\hline & \multicolumn{2}{|c|}{ Marriage } & \multicolumn{2}{|c|}{ Cohabitation } & \\
\hline & $M$ & $S D$ & M & $S D$ & \\
\hline Men & 44.44 & 13.46 & 55.21 & 8.38 & $<.0005$ \\
\hline Women & 42.47 & 13.29 & 55.03 & 8.14 & $<.0005$ \\
\hline \multirow[t]{2}{*}{$\begin{array}{l}p \text { in interaction effect test } \\
\text { (between genders) }\end{array}$} & \multicolumn{2}{|c|}{.065} & \multicolumn{2}{|c|}{.917} & $\begin{array}{l}p \text { in interaction effect test: } \\
\text { type of relationship* gender } .378\end{array}$ \\
\hline & $M$ & $S D$ & $M$ & $S D$ & Significance of the relationship \\
\hline Men & 22.66 & 7.71 & 20.98 & 5.47 & .041 \\
\hline Women & 23.19 & 7.06 & 21.70 & 5.48 & .026 \\
\hline \multirow[t]{2}{*}{$\begin{array}{l}p \text { in interaction effect test } \\
\text { (between genders) }\end{array}$} & \multicolumn{2}{|c|}{.172} & \multicolumn{2}{|c|}{.461} & $\begin{array}{c}p \text { in interaction effect test: } \\
\text { type of relationship* gender } .927\end{array}$ \\
\hline & M & $S D$ & M & $S D$ & Concern for the partner's well-being \\
\hline Men & 14.22 & 4.91 & 13.43 & 5.47 & .176 \\
\hline Women & 13.08 & 4.63 & 12.14 & 5.13 & .100 \\
\hline $\begin{array}{l}p \text { in interaction effect test } \\
\text { (between genders) }\end{array}$ & \multicolumn{2}{|c|}{.008} & \multicolumn{2}{|c|}{.064} & $\begin{array}{c}p \text { in interaction effect test: } \\
\text { type of relationship* gender } .856\end{array}$ \\
\hline
\end{tabular}

Table 2

Results for dependencies among type of relationship and bond with the partner, significance of the relationship, concern for the partner's well-being

\begin{tabular}{ccccc}
\hline \multicolumn{5}{c}{ Type of relationship } \\
\hline \multicolumn{4}{c}{ Marriage } & \multicolumn{2}{c}{ Cohabitation } & Bond with the partner \\
\hline$M$ & $S D$ & $M$ & $S D$ & $p$ in expected values comparison test \\
43.36 & 13.39 & 55.12 & 8.24 & $<.0005$ \\
\hline \multicolumn{4}{c}{ Marriage } & \multicolumn{2}{c}{ Cohabitation } & Significance of the relationship \\
\hline$M$ & $S D$ & $M$ & $S D$ & $p$ in expected values comparison test \\
23.11 & 7.37 & 21.34 & 5.47 & .003 \\
\hline \multicolumn{4}{c}{ Marriage } & \multicolumn{2}{c}{ Cohabitation } & Concern for the partner's well-being \\
\hline M & $S D$ & $M$ & $S D$ & $p$ in expected values comparison test \\
\hline
\end{tabular}

married women with cohabiting women $(p<.05)$ (Table 1). Gender was not found to differentiate the significance of the relationship $(p>.05)$. It is possible that the factor that decides about the dependent character and significance of a relationship is its type. In Poland, a married person is often perceived to be of higher status than an unmarried one. The traditional approach to family remains dominant in Polish culture, and is reinforced by government family policy, which does not consider cohabitation.
In the married relationships, a significant difference can be seen between sexes regarding concern for the partner's well-being. Men are more constrained from leaving their wives by feeling concern for them than vice versa $(p<.05)$. Such differences were not observed for cohabitations (Table 1). Interestingly, a comparison between marriages and cohabitations (Table 2) indicates that fears regarding leaving the relationship are greater in married partners than in the cohabiting ones $(p<.05)$. Married persons were 
found to anticipate greater negative consequences regarding separation, for both the person who leaves the relationship and the abandoned person, with regard to their feelings and life difficulties. Hence, a significantly stronger obligation to stay in the relationship was observed in marriages as compared to cohabitations $(p<.05)$.

\section{DISCUSSION}

In the Polish version of the Commitment Inventory, only 19 items among three factors were found significant ${ }^{1}$. The factors were bond with the partner, significance of the relationship and concern for the partner's well-being. This adaptation of the instrument has confirmed the original theoretical assumptions adopted by Stanley and Markman (1992), namely the existence of the two commitment constructs: dedication and constraint commitment.

It was assumed that the essence of commitment, dedication, derives from building mutual psychological and physical dependence between partners. It presents an indispensable dimension in satisfying relations between partners in close dyadic relationships. Emotional interdependence results in striving for closeness and frequent contact. The component of commitment known as dedication, i.e. the wish to remain in the relationship, only refers to the will to maintain the relationship. However, it is empirically justified to conclude that the stability of a relationship is not necessarily related to its quality: it is possible that one partner may perceive leaving the relationship as being particularly difficult for themselves or their partner, and such fears may force them to stay in the relationship, even when the emotional bond between the partners weakens and the relation they create becomes of little importance in their lives. Hence the second component, constraint commitment, interpreted as obligations that hinder partners from leaving the relationship, may be treated as a good predicator of its stability.

Some other studies indicate that not all the factors restricting exit from the relationship should be referred to as significant for commitment. It appears that alternatives for the relationship and investments are weaker predicators for commitment (Hadden, Knee, DiBello, \& Rodriguez, 2015; Lemay, 2016), and contemporary adults are less sensitive to social pressure regarding continuation of the relationship (Owen et al., 2011), which may weaken the influence of these factors. The awareness of a compulsion to be in the relationship because of the constraints mentioned above may raise the sense of being trapped and increase dislike for the partner.

Concern for the partner's well-being, which was a significant dimension in the Polish studies, ought to be treated as an obligation rather than a specific limitation. Its internal character may hinder a partner from leaving the relationship and, in a longer perspective, act to benefit the relationship to a greater extent than external constraints such as financial situation or social pressure. Concern for the partner's well-being also has an interpersonal dimension, which makes it similar to the two considered factors of dedication: bond with the partner and significance of the relationship.

The present study compares the commitment between cohabiting and married couples. It was found that a cohabiting relationship is based mainly upon one of the dedication dimensions, bond with the partner, while a marital relationship is based on dedication regarding the significance of the relationship and constraint commitment.

A permanent relationship requires not only mutual dedication but also some specific obligations. Cohabitation is to a lesser degree orientated towards the obligations restricting exit from the relationship than marriage. Earlier studies (Janicka, 2006) have shown that the emotional bond is the basic factor which integrates partners in cohabitation, and that the relationship lasts as long as the partners love one another. Hsueh, Morrison, and Doss (2009) indicate that the relationship between cohabitants is more intense than that between spouses, but also more ephemeral. Cohabiting couples experience more problems regarding commitment regarding earlier relationships, solving conflicts, uncertainty of the partner's feelings, forming goals for the future and defining values. These problems may have a negative influence on the level of commitment, which usually appears to be lower than in spouses. Cohabitation does not portend well for commitment (Hsueh et al., 2009; Pryor \& Roberts, 2005; Rhoades et al., 2012b; Stanley et al., 2004). The emotional bond, which is the only basis for cohabitation, is sometimes disturbed or even eliminated when partners lead a diverse professional or social life. These obligations demand different forms of attention and limit their possibilities of spending time together (Hohenster, 2000). The marital obligation is stronger than that of cohabitation: the stability of marriage is reinforced by the existence of greater limitations on leaving the relationship. Indeed, it has been empirically confirmed that marriages tend to be more stable and more long-lasting than cohabitations (Brown \& Booth, 1996; Ermisch \& Francesconi, 1998; Lichner \& Qian, 2008; Nave-Herz, 2002; Schoen \& Weinick, 1993; Seltzer, 2000).

Gender did not appear to play a significant role in the dimensions of commitment concerning dedication, i.e. bond with the partner and significance of the relationship. Nevertheless, it does also seem to have a significant influence on constraint commitment: concern for the partner's well-being. However, unlike the women, the married men tended to feel more concern for their partner's well-being than the cohabiting men, which may significantly limit the chances of 
the former leaving the relationship. This is a surprising result, as it is widely assumed that women engage more fully in a permanent relationship than men (Baxter, Haynes, \& Hewitt, 2010; Kaźmierczak, 2008; Wojciszke, 2009). However, it turns out that in Poland, women are as much as twice as likely to file for divorce as men, indicating that the women tend to make the decision to leave the relationship (General Statistical Office, 2016). However, this fact alone cannot thoroughly justify the conclusion that women exhibit less concern for their partners, and it is undoubtedly necessary to examine some other individual determinants of commitment besides the sex of the partner.

The present findings indicate that marriages tend to portend better than cohabitations. The permanence of marriage is based on dedication, reflecting the significance of the relationship, and constraint commitment, which regards concern for the partner's well-being. The latter may hinder partners, especially men, from leaving the relationship. Studies (Park, Impett, MacDonald, \& Lemay, 2019) have shown that partners' expression of their grateful feelings, when perceived, may serve as a reminder of the communal nature of the relationship, and can have positive effects on romantic relationships.

It may be concluded that cohabitation, as a form of common life that does not assume permanence of the relationship, is often not treated seriously by its participants and its nature absolves them of obligations for the partner. One cannot also exclude the idea that cohabitation is chosen by persons who do not treat the relationship seriously, which at the same time eliminates or limits their obligations for the partner.

Studies conducted in Poland tend to produce very similar results to those performed in the US concerning the level of commitment by partners in cohabiting relationships. It may be concluded that the type of commitment is specified more closely by the form of the relationship rather than the socio-cultural conditions in which the couples live.

\section{ENDNOTE}

1 The original version initially comprised 105 items; however, after modifications, this number was reduced to 55 items. A later verification of the method by Owen et al. (2011) on the basis of examining cohabiting couples, reduced the number of items to 25 for seven factors: six factors regarding bond and one factor for sacrifice.

\section{RefERENCES}

Baxter, J., Haynes, M., \& Hewitt, B. (2010). Pathways into marriage: Cohabitation and the domestic division of labour. Journal of Family Issues, 31, 1507-1529.
Binstock, G. (2003). Separations, reconciliations and living apart in cohabiting and marital unions. Journal of Marriage and Family, 65, 432-443.

Brown, S. I., \& Booth, A. (1996). Cohabitation versus marriage: A comparison of relationship quality. Journal of Marriage and the Family, 58, 668-678.

Brown, S. L. (2003). Relationship quality dynamics of cohabitating unions. Journal of Family Issues, 24, 583-601.

Carswell, K. L., \& Finkel, E. J. (2018). Can you get the magic back? The moderating effect of passion decay beliefs on relationship commitment. Journal of Personality and Social Psychology, 115, 1002-1033.

Chechliński, W. (1981). Kohabitacja - nowe zjawisko życia rodzinnego [Cohabitation - a new phenomenon in family life]. In M. Ziemska \& A. Kwak (Eds.), Funkcjonowanie rodziny a problemy profilaktyki spotecznej i resocjalizacji [Family functioning and problems of social prevention and rehabilitation] (pp. 27-35). Warszawa: Wydawnictwo Uniwersytetu Warszawskiego.

Ermisch, J., \& Francesconi, M. (1998). Cohabitation in Great Britain: Not for long, but here to stay. Colchester: ISER, University of Essex.

General Statistical Office (2016). Demographic Yearbook of Poland. Warsaw: General Statistical Office.

Givertz, M., Burke, T., Segrin, C., \& Woszidlo, A. (2016). Attachment orientation moderates the relationship between dedication and constraint commitment and felt constraint in married couples. Couple and Family Psychology: Research and Practice, 1, 1-11.

Givertz, M., Segrin, C., \& Hanzal, A. (2009). The association between satisfaction and commitment differs across marital couple types. Communication Research, 36, 561-584.

Givertz, M., Segrin, C., \& Woszidlo, A. (2016a). Direct and indirect effects of commitment on interdependence and satisfaction in married couples. Journal of Family Psychology, 30, 214-220.

Gold, K. J., Sen, A., \& Hayward, R. A. (2010). Marriage and cohabitation outcomes after pregnancy loss. Pediatrics, 5, 125-202.

Hadden, B. W., Knee, C. R., DiBello, A. M., \& Rodriguez, L. M. (2015). High alternatives, low investments, no problem: A motivation perspective on the investment model. Motivation Science, 1, 244-261.

Hohenester, B. (2000). Dyadische Einheit. Zur sozialen Konstitution der ehelich Beziehung [Dyadic unit. On the social constitution of marital relationship]. Konstanz: UVK Universitätsverlag Konstanz $\mathrm{GmbH}$.

Hsueh, A. C., Morrison, K. R., \& Doss, B. D. (2009). Qualitative reports of problems in cohabiting relationships: Comparisons to married and dating relationships. Journal of Family Psychology, 23, 236-246. 
Janicka, I. (2006). Kohabitacja a matżeństwo w perspektywie psychologicznej [Cohabitation and marriage in psychological perspective]. Łódź: Wydawnictwo Uniwersytetu Łódzkiego.

Janicka, I. (2008). Stosunki partnerskie w związkach niemałżeńskich [Partnership in nonmarital relationships]. Przegląd Psychologiczny, 1, 37-53.

Janicka, I. (2009). Ryzyko kryzysów i konfliktów w związkach kohabitacyjnych [The risk of crises and conflicts in cohabiting relationships]. Przegląd Psychologiczny, 52, 293-308.

Janicka, I. (2010). Jakość małżeństw poprzedzonych kohabitacją [Quality of marriages preceded by cohabitation]. In T. Rostowska \& A. Peplińska (Eds.), Psychospołeczne aspekty życia rodzinnego [Psychosocial aspects of family life] (pp. 94-109]. Warszawa: Difin.

Janicka, I., \& Szymczak, W. (2017). Kwestionariusz zaangażowania interpersonalnego - polska adaptacja [Interpersonal Commitment Questionnaire polish adaptation]. Polskie Forum Psychologiczne, 2, 205-218.

Kaźmierczak, M. (2008). Oblicza empatii w relacjach matżeńskich [Faces of empathy in marital relationships]. Gdańsk: Wydawnictwo Uniwersytetu Gdańskiego.

Kelmer, G., Rhoades, G. K., Stanley, S., \& Markman, H. J. (2013). Relationship quality, commitment, and stability in long-distance relationships. Family Process, 52, 257-270.

Keong-il, K. (2008). Alternative forms of marriage and family in colonial Korea. The Review of Korean Studies, 11, 61-82.

Kline, G. H., Stanley, S. M., Markman, H. J., Olmos-Gallo, P. A., Peters, M. S., Whitton, S. W., \& Prado, L. M. (2004). Timing is everything: Pre-engagement cohabitation and increased risk for poor marital outcomes. Journal of Family Psychology, 2, 311-318.

Knopp, K. C., Rhoades, G. K., Stanley, S. M., \& Markman, H. J. (2015). Stuck on you: How dedication moderates the way constraints feel. Journal of Social and Personal Relationships, 32, 119-137.

Landis, M., Bodenmann, G., Bradbury, T. N., Brandstätter, V., Peter-Wight, M., Backes, S., SutterStickel, D., \& Nussbeck, F. W. (2014). Commitment and dyadic coping in long-term relationships. GeroPsych, 27, 139-149.

Lemay, E. P. (2016). The forecast model of relationship commitment. Journal of Personality and Social Psychology, 111, 34-52.

Lichner, D. T., \& Qian, Z. (2008). Serial cohabitation and the marital life course. Journal of Marriage and the Family, 70, 861-878.

Mortensen, O., Torsheim, T., Melkevik, O., \& Thuen, F. (2012). Adding a baby to the equation. Married and cohabiting women's relationship satisfaction in the transition to parenthood. Family Process, 51, 122-139.
Nave-Herz, R. (2002). Wandel und Kontinuität in der Bedeutung, in der Struktur und Stabilität von Ehe und Familie in Deutschland [Change and continuity in the meaning, in the structure and stability of marriage and family in Germany]. In R. NaveHerz (Ed.), Kontinuität und Wandel der Familie in Deutschland [Continuity and change of the family in Germany] (pp. 45-69). Stuttgart: Enke.

Nave-Herz, R. (2003). Familie zwischen Tradition und Moderne [Family between tradition and modernity]. Oldenburg: Bibliotheks- und Informationssystem der Universität Oldenburg.

Owen, J., Rhoades, G. K., Stanley, S. M., \& Markman, H. J. (2011). The Revised Commitment Inventory: Psychometrics and use with unmarried couples. Journal of Family Issues, 32, 820-841.

Park, Y., Impett, E. A., MacDonald, G., \& Lemay, E. P. Jr. (2019). Saying "thank you": Partners' expressions of gratitude protect relationship satisfaction and commitment from the harmful effects of attachment insecurity. Journal of Personality and Social Psychology. https://doi.org/10.1037/pspi0000178

Popenoe, D., \& Whitehead, B. (2004). The State of Our Unions. The National Marriage Project. New Brunswick, NJ: Rutgers, The State University of New Jersey.

Pryor, J., \& Roberts, J. (2005). What is commitment? How married and cohabiting parents talk about their relationship. Family Matters, 71, 24-31.

Rhoades, G. K., Stanley, S. M., Kelmer, G., \& Markman, H. J. (2010). Physical aggression in unmarried relationships: the roles of commitment and constraints. Journal of Family Psychology, 6, 678-687.

Rhoades, G. K., Stanley, S. M., \& Markman, H. J. (2006). Pre-engagement cohabitation and gender asymmetry in marital commitment. Journal of Family Psychology, 20, 553-560.

Rhoades, G. K., Stanley, S. M., \& Markman, H. J. (2009). Couples relations for cohabitation: Associations with individual well-being and relationship quality. Journal of Family Issues, 2, 233-258.

Rhoades, G. K., Stanley, S. M., \& Markman, H. J. (2012a). The impact of the transition to cohabitation on relationship functioning: Cross-sectional and longitudinal findings. Journal of Family Psychology, 26, 348-358.

Rhoades, G. K., Stanley, S. M., \& Markman, H. J. (2012b). A longitudinal investigation of commitment dynamics in cohabiting relationships. Journal of Family Issues, 33, 369-390.

Schoebi, D., Karney, B. R., \& Bradbury, T. N. (2012). Stability and change in the first 10 years of marriage: Does commitment confer benefits beyond the effects of satisfaction. Journal of Personality and Social Psychology, 102, 729-742

Schoen, R., \& Weinick, M. (1993). Partner choice in marriages and cohabitations. Journal of Marriage and the Family, 55, 408-414. 
Seltzer, J. (2000). Families formed outside of marriage. Journal of Marriage and the Family, 62, 1247-1268.

Smock, P. (2000). Cohabitation in the United States: An appraisal of research themes, findings and implications. Annual Review of Sociology, 26, 1-20.

Stanley, S., \& Markman, H. (1992). Assessing commitment in personal relationships. Journal of Marriage and the Family, 54, 595-608.

Stanley, S. M., Rhoades, G. K., \& Markman, H. J. (2006). Sliding versus deciding: Inertia and the premarital cohabitation effect. Family Relations, 55, 499-509.

Stanley, S. M., Whitton, S. W., \& Markman, H. J. (2004). Maybe I do: Interpersonal commitment and premarital or non-marital cohabitation. Journal of Family Issues, 25, 496-519.

Thomson, E., \& Colella, U. (1992). Cohabitation and marital stability: Quality or commitment? Journal of Marriage and the Family, 54, 259-267.

Winer, B. J., Brown, D. R., \& Michels, K. M. (1991). Statistical Principles in Experimental Design. Third Edition. Boston: McGraw-Hill, Inc.

Wojciszke, B. (2009). Psychologia mitości [Psychology of Love]. Gdańsk: Gdańskie Wydawnictwo Psychologiczne.

Xu, X., Hudspeth, C. D., \& Bartkowski, J. P (2006). The role of cohabitation in remarriage. Journal of Marriage and Family, 68, 261-274. 